\title{
Isolation, identification and 16S rRNA gene analysis of Yersinia enterocolitica strains isolated from the Gymnocypris przewalskii
}

Hongjian Zhang ( $\sim 707879673 @ q q . c o m$ )

Qinghai University

Qigang Cai

Qinghai University

Jing Zhao

Qinghai University

Yuxia Fan

Qinghai University

Fanlin Kong

Qinghai University

Xiaolong Gao

Qinghai University

Linna Tong

Qinghai University

\section{Research Article}

Keywords: fish, Yersinia enterocolitica, isolation, drug sensitive fauna test

Posted Date: March 30th, 2020

DOl: https://doi.org/10.21203/rs.3.rs-19869/v1

License: (c) (i) This work is licensed under a Creative Commons Attribution 4.0 International License.

Read Full License 


\section{Abstract}

Background: Yersinia enterocolitica is a human-animal-fish-associated infectious diarrhea pathogen that has caused widespread international attention in recent years. Many strains of Yersinia enterocolitica were identified from different animal species, but there is no information reported Yersinia enterocolitica in Gymnocypris przewalskii. The Gymnocypris przewalskii is a very important species in the Qinghai Lake. They were listed in the China's second-class protected animal species. Preliminary research on the distribution of Yersinia enterocolitica and the drug sensitive fauna test on Gymnocypris przewalskii was a urgent solving problem for which maintain the original ecological symbiotic system and restore Gymnocypris przewalskii resource. In order to solve these issues, we performed this research.

Methods: Pathogen of Yersinia enterocolitica of 75 death Gymnocypris przewalskii was isolated by routine isolation culture and identification technique in fishing bank of Xining. At the same time, the drug sensitive fauna test had been detected. At the meantime, 16S rRNA gene of Yersinia enterocolitica was cloned and sequences identified.

Results: The results showed that 5 strains Yersinia enterocolitica were obtained, positive ratio was $6.67 \%$ (5/75). 1 strains bacteria had lethal effect to mice by pathogenic test. The average drug-resistant of 5 strain Yersinia enterocolitica was $54.29 \%(38 / 70)$ to 14 kinds of antibiotic. The result of 16 S rRNA gene of Yersinia enterocolitica identified showed that one piece of $1419 \mathrm{bp}$ specific braid was obtained. The homologies of nucleotide of 16S rRNA were $91 \%-95 \%$ between 15 strains of Yersinia enterocolitica from GenBank by measuring sequence.

Conclusion: Yersinia enterocolitica can infect Gymnocypris przewalskii. Some strains cause lethal effect to mice and have drug-resistant effect. The 16S rRNA gene matches $91 \%-95 \%$ with other strains nucleotides download from GenBank and forms a unique branch separated from them.

Trial registration: During this research, we didn't need to apply for trail and have no trial registration number.

\section{Introduction}

Yersinia enterocolitica is a human-animal-fish-associated infectious diarrhea pathogen that has caused widespread international attention in recent years. Yersiniasis caused by Yersinia enterocolitica is the third most common zoonotic disease followed by Salmonella and Campylobacter in some European countries[1]. It can often cause the respiratory, cardiovascular systems, bones and connective tissues diseases[2, 3], making the disease with poor prognosis or death due to sepsis[4]. At present, the bacteria have been isolated from various mammals, oviparous animals, agricultural products and animal products in China and abroad[5-10]. However, no reports of Yersinia enterocolitica from Gymnocypris przewalskii in Qinghai Lake have been seen. 
The Gymnocypris przewalskii belongs to the Gymnocypris, Schizothoracinae, Cyprinidae, Cypriniformes and common called 'Huangyu'. It is the only aquatic economic animal in Qinghai lake and its water system. At the end of the last century, due to the shrinking water area of the Qinghai Lake, the deterioration of the water environment, the frequent occurrence of various diseases and the overfishing of spawning and spawning, the phenomenon of spawning and spawning of broods tock was repeatedly banned. In addition, the hatching rate of fertilized eggs of broods tock in the natural state was less than $5 \%$ and their growth was very slow (Gains about $0.15 \mathrm{~kg}$ every 10 years), leading to a sharp decline in the population base to about 2000t. With the increasing intensity of lake closure and artificial seedling release in Qinghai Lake in recent years, although the population base has reached 88,000 tons, it is still less than one third of the 1960s. At present, researches on Gymnocypris przewalskii in Qinghai Lake are mostly focused on biology and parasitic diseases, while research on pathogenic microorganisms is almost blank.

\section{Materials}

\section{Materials}

\section{Samples collection}

75 pancreas of Qinghai Lake naked carp that had died one after another in a fishery of a naked carp rescue center in Qinghai Province were aseptically collected and numbered, and placed in a refrigerator at $4{ }^{\circ} \mathrm{C}$ for use.

\section{Control strains}

Escherichia coli (ATCC25922) and Salmonella typhimurium (ATCC14028) were donated by the Department of Preventive Veterinary Medicine, China Agricultural University.

\section{Growth medium and molecular reagents}

The Improved Phosphate Buffer Solution (PBS), modified $\mathrm{Y}$ and $\mathrm{CIN}-1$ plates, and modified Kirschner's disaccharide iron bevel (KIA) were made in our laboratory. Glucose and other 24 biochemical media were purchased from Beijing Luqiao Technology Co., Ltd. (batch number: 20180611). Bacterial DNA extraction kit, gel recovery kit, Taq DNA polymerase and pMD18-T vector were purchased from TaKaRa.

\section{Primers}

The primers sequences are P1 5'CGCGGATCCATTGAACGCTGGCGGCAG3' and P2 5'GGGGTACCCCTACGGTTACCTTGTTACGACTTC3'. They were synthesized by Shanghai Biotech Biotechnology Service Co., Ltd.

\section{Drug sensitive paper}


14 kinds of drug sensitive paper such as chloramphenicol were purchased from Hangzhou Microbial Reagent Co., Ltd. (Lot No .: 20180290).

\section{Experimental animals}

18 healthy Kunming mice were purchased from Qinghai Institute for Endemic Diseases Prevention and Control (15-20g).

\section{Methods}

Isolation and identification of Yersinia enterocolitica from naked carp of Qinghai Lake.

\section{Sample enrichment}

Cut a few samples aseptically and inoculate them in PSB, and incubate them at $26^{\circ} \mathrm{C}$ for $48 \pm 2 \mathrm{~h}$.

\section{Sample alkali treatment}

Take $1 \mathrm{~mL}$ of the bacterial growth solution and add it to $9 \mathrm{~mL}$ of $0.4 \% \mathrm{KOH}$ solution (containing $0.5 \%$ $\mathrm{NaCl}$, prepared before use), which is warmed to $26^{\circ} \mathrm{C}$, and mix for $30 \mathrm{~s}$.

\section{Isolation and purification of bacteria}

Alkali-treated bacteria-enriching solution was streaked on $\mathrm{CIN}-1$ and modified $\mathrm{Y}$ plates, and cultured at 26

${ }^{\circ} \mathrm{C}$ for $48 \pm 2 \mathrm{~h}$. After that, the suspect colony smears were picked, and Gram staining microscopy was performed, and several purification cultures were performed.

\section{Screening of bacteria}

Five suspicious colonies on $\mathrm{CIN}-1$ and modified $\mathrm{Y}$ plate were picked in turn and tested on KIA oblique urea and semi-solid medium, and the results were observed.

\section{Smear, Gram stain and microscopy}

Bacteria that were positive at $26^{\circ} \mathrm{C}$ and negative at $37^{\circ} \mathrm{C}$ in the secondary rescreening test were picked for smear and Gram staining microscopy.

\section{Biochemical identification}

The suspected strains screened by the primary and secondary screening tests were aseptically inoculated into 27 biochemical reaction tubes such as glucose and cultured at $26^{\circ} \mathrm{C}$ for $48 \pm 2 \mathrm{~h}$, and the results were observed.

\section{Drug sensitive test}


The purified strains were individually inoculated into a modified $Y$ slant, cultured at $26^{\circ} \mathrm{C}$ for 24 hours, and then washed under sterile conditions with sterile physiological saline, and were turbid with a Macquarie tube. A bacterial suspension at a concentration of $9 \times 10^{8}$ live bacteria / $\mathrm{mL}$ was selected, and the bacterial solution was dipped in a sterile cotton swab to uniformly coat the $\mathrm{MH}(\mathrm{A})$ plate 3 times. Then, 16 kinds of drug-sensitive papers were respectively put on in order, 3 pieces were put on each plate, and the results were determined by incubating at $37^{\circ} \mathrm{C}$ for $18-24 \mathrm{~h}$.

\section{Pathogenicity test}

Take the above-mentioned concentration of bacterial solution in order to inject the mice by intraperitoneal injection, 3 mice per strain, $0.5 \mathrm{~mL}$ per mouse, and inject 3 mice with sterilized saline as a control, then observe the results.

\section{Cloning of $16 S$ rRNA gene}

\section{Template DNA Extraction}

The operation steps are performed according to the instruction manual of MiniBEST Bacterial Genomic DNA Extraction Kit.

\section{PCR reaction system and conditions}

PCR reaction system (50 $\mu \mathrm{L})$ : Premix Taq $25 \mu \mathrm{L}, \mathrm{P} 1$ and P2 primers $1 \mu \mathrm{L}$ each, DNA template $1 \mu \mathrm{L}, \mathrm{ddH} 20$ $22 \mu \mathrm{L}$; PCR reaction conditions: $94{ }^{\circ} \mathrm{C}$ pre-denaturation for $5 \mathrm{~min}, 94{ }^{\circ} \mathrm{C}$ denaturation for $30 \mathrm{~s}, 55^{\circ} \mathrm{C} 30 \mathrm{~s}$, $72{ }^{\circ} \mathrm{C}$ for $30 \mathrm{~s}$, a total of 35 cycles, $72{ }^{\circ} \mathrm{C}$ extended 10 minutes.

\section{$16 \mathrm{~S}$ rRNA Gene Cloning and Sequence Analysis}

The PCR amplified product recovered from the gel was cloned, PCR identified and sequenced 3 times. The 16S rRNA sequence of Yersinia enterocolitica from naked carp of Qinghai Lake was performed on GenBank and 15 representative strains of China and abroad Homology analysis.

\section{Results}

\section{Routine isolation and identification of Yersinia enterocolitica from naked carp of Qinghai Lake}

\section{Colony morphology and culture characteristics}

Red bull-eye colonies appeared on CIN-1. Colorless and transparent, non-sticky colonies appeared on modified Y. Gram staining microscopic examination showed short rod-shaped Gram-negative bacilli or cocci, mostly scattered individually, sometimes arranged in short chains or piles, without spores and capsules.

\section{Screening of bacteria}


After preliminary screening tests, 20 strains of KIA with yellow and non-gas-producing strains were obtained on the slope and bottom of KIA. Fifteen urea-positive strains were obtained by rescreening. Two rescreening yielded 5 strains of $26^{\circ} \mathrm{C}$ cultured with motility, and $37^{\circ} \mathrm{C}$ cultured non-motility strains, which were classified as Y1301, Y1302, Y1303, Y1304, Y1305.

\section{Biochemical identification}

See Table 1 for details.

Table 1. The result of biochemical characterisitic of Yersinia enterocolitica

\begin{tabular}{|c|c|c|c|c|c|c|}
\hline \multicolumn{2}{|r|}{ Items } & Y1301 & Y1302 & Y1303 & Y1304 & Y1305 \\
\hline \multicolumn{2}{|r|}{ GLU } & प & प & 0 & प & प \\
\hline \multicolumn{2}{|r|}{ LAC } & प & ] & प & ] & प \\
\hline \multicolumn{2}{|r|}{ MAL } & Q & प & प & प & प \\
\hline \multicolumn{2}{|r|}{ SUC } & 口 & प & प & ] & 口 \\
\hline \multicolumn{2}{|r|}{ Trehalose } & Q & प & Q & प & प \\
\hline \multicolumn{2}{|r|}{ RHA } & 口 & 口 & 口 & 口 & 口 \\
\hline \multicolumn{2}{|r|}{ Raffinose } & Q & प & प & प & प \\
\hline \multicolumn{2}{|r|}{ ARA } & प & ] & प & 口 & 口 \\
\hline \multicolumn{2}{|r|}{$X Y L$} & Q & प & Q & ए & ૫ \\
\hline \multicolumn{2}{|r|}{ MON } & प & 口 & Q & प & प \\
\hline \multicolumn{2}{|r|}{ SOR } & Q & प & 口 & ] & प \\
\hline \multicolumn{2}{|r|}{ DUL } & प & प & Q & प & Q \\
\hline \multicolumn{2}{|r|}{ SAL } & Q & ए & 口 & ] & 口 \\
\hline \multicolumn{2}{|r|}{ INO } & प & प & प & $\square$ & प \\
\hline \multicolumn{2}{|r|}{ ODC } & Q & प & 口 & ] & 口 \\
\hline \multicolumn{2}{|r|}{ TRP } & प & $\square$ & प & $\square$ & प \\
\hline \multicolumn{2}{|r|}{ CIT } & Q & 口 & Q & ए & प \\
\hline \multicolumn{2}{|r|}{ NTT } & प & $\square$ & प & $\square$ & प \\
\hline \multicolumn{2}{|r|}{ URE } & Q & प & प & 口 & 口 \\
\hline \multirow[t]{2}{*}{ Semi-solid } & $26^{\circ} \mathrm{C}$ & प & प & Q & प & ૫ \\
\hline & $37^{\circ} \mathrm{C}$ & 口 & ] & 口 & ] & 口 \\
\hline \multicolumn{2}{|r|}{ GEL } & Q & ] & Q & प & प \\
\hline \multicolumn{2}{|r|}{$\mathrm{MR}$} & 口 & 口 & 口 & ए & 口 \\
\hline \multirow[t]{4}{*}{ V-P } & $26^{\circ} \mathrm{C}$ & प & ] & 口 & 口 & 口 \\
\hline & $37^{\circ} \mathrm{C}$ & 口 & ] & Q & 口 & 口 \\
\hline & $\mathrm{H}_{2} \mathrm{~S}$ & प & ] & प & ] & 口 \\
\hline & IND & ૧ & [ & ૧ & [ & प \\
\hline
\end{tabular}

Note: "+" means positive, "-" means negative 


\section{Drug sensitive test}

The results are as follows (Tab.2)

Table 2. Sensitive Test of 14 kinds of Medicine for 5 strains Yersinia enterocolitic

\begin{tabular}{ccccccccc}
\hline Antibiotics & Y1301 & Y1302 & Y1303 & Y1304 & Y1305 & Resistance & intermediary & Sensitivity \\
\hline AZI & S & R & R & S & R & $60 \%$ & $0.00 \%$ & $40 \%$ \\
GMIO & S & S & S & S & I & $0.00 \%$ & $20 \%$ & $80 \%$ \\
CH & R & R & R & R & R & $100 \%$ & $0.00 \%$ & $0.00 \%$ \\
E & R & R & S & I & R & $60 \%$ & $20 \%$ & $20 \%$ \\
AN & S & R & S & R & I & $40 \%$ & $20 \%$ & $40 \%$ \\
CAZ & R & R & I & R & S & $60 \%$ & $20 \%$ & $20 \%$ \\
PIP & R & S & R & S & I & $40 \%$ & $20 \%$ & $40 \%$ \\
TE & I & I & S & R & I & $20 \%$ & $60 \%$ & $20 \%$ \\
TM & S & S & S & R & S & $20 \%$ & $0.0 \%$ & $80 \%$ \\
CMZ & R & R & R & R & S & $80 \%$ & $0.00 \%$ & $20 \%$ \\
K & R & R & R & S & I & $60 \%$ & $20 \%$ & $20 \%$ \\
S 300 & R & R & R & I & R & $80 \%$ & $20 \%$ & $0.00 \%$ \\
SXT & R & R & R & R & I & $80 \%$ & $20 \%$ & $0.00 \%$ \\
C & R & S & R & R & S & $60 \%$ & $0.00 \%$ & $40 \%$ \\
\hline
\end{tabular}

\section{Pathogenicity test}

All mice in the test group died after 48 hours, and the control mice remained alive after one week of feeding. It was proved that the isolated strain had a lethal effect on mice. Examination of dead mice showed hepatomegaly, dark spleen, a small amount of fluid in the pericardium, and intestinal necrosis in some sections. Aseptic examination of the liver and spleen with contact pad staining microscopy showed short rod-shaped or oval Gram-negative Spores and capsular bacteria, and the pathogenic bacteria were isolated from dead rat livers, and then biochemically identified. The results showed that the biochemical results of pathogenic bacteria isolated from the liver of dead mice and isolated from naked carp of Qinghai Lake were completely consistent.

\section{S rRNA gene colon}

PCR amplification of 16S rRNA gene of Yersinia enterocolitica from naked carp of Qinghai Lake (Fig 1).

\section{PCR specificity test of wild isolates and control bacteria}

The PCR specificity test of 16s rRNA gene was performed on Y1301 and Y1302 strains with P1 and P2 primers, respectively. The target fragment of $1419 \mathrm{bp}$ in size consistent with the expected results was 
obtained (Fig.2).

\section{Sensitivity test of isolated strains}

A single clone of Y1301 was aseptically inoculated into LB Amp + liquid medium, cultured at $26^{\circ} \mathrm{C}$ for 12 hours, and genomic DNA was extracted. The extracted DNA was diluted 10-fold to $10^{-10}$ in turn, and P1 and P2 primer pairs were applied respectively. The PCR amplification of 16S rRNA gene was performed, and the obtained PCR product was subjected to electrophoresis, and the results showed that a dilution of $10^{-6}$ was detectable (Fig.3).

\section{Homologous analysis of sequence of Y.e 16S rRNA gene from naked carp of Qinghai Lake}

The nucleotide sequence comparison showed that the nucleotide homology of Y1301, Y1303 and Y1304 was $100 \%$; the homology of $\mathrm{Y} 1302$ and $\mathrm{Y} 1305$ was $100 \%$, and there were no mutation sites. AJ639645, HE803738, HE803739, HE803740, HE803741, HE803742, HE803743, HE803744, HE803745, HE803748, HE803750, HE803756, HE803758, HE803762, HE803792 are in sites of $28^{\text {th }}, 72^{\text {th }}, 75^{\text {th }}, 81^{\text {th }}, 84^{\text {th }}, 101^{\text {th }}$, $112^{\text {nd }}, 154^{\text {th }}, 299^{\text {th }}, 325^{\text {th }}, 346^{\text {th }}, 347^{\text {th }}, 351^{\text {st }}, 352^{\text {nd }}, 359^{\text {th }}, 361^{\text {st }}, 362^{\text {nd }}, 366^{\text {th }}, 367^{\text {th }}, 481^{\text {st }}, 485^{\text {th }}$, $491^{\text {st }}, 507^{\text {th }}, 511^{\text {st }}, 515^{\text {th }}, 529^{\text {th }}, 540^{\text {th }}, 702^{\text {nd }}, 729^{\text {th }}, 739^{\text {th }}, 806^{\text {th }}, 816^{\text {th }}, 867^{\text {th }}, 892^{\text {nd }}, 893^{\text {th }}, 897^{\text {th }}$, $912^{\text {nd }}, 913^{\text {th }}, 928^{\text {th }}, 929^{\text {th }}, 992-997^{\text {th }}, 998^{\text {th }}-1006^{\text {th }}, 118^{\text {th }}, 1010^{\text {th }}-1012^{\text {nd }}, 1016^{\text {th }}-1017^{\text {th }} 1020^{\text {th }}$ $-1025^{\text {th }}, 1041^{\text {st }}-1042^{\text {nd }}, 1046^{\text {th }}, 1050^{\text {th }}-1055^{\text {th }}, 1057^{\text {th }}-1067^{\text {th }}, 1070^{\text {th }}-1073^{\text {th }}, 1076^{\text {th }}-1077^{\text {th }}, 1078$ th $-1079^{\text {th }}$, and $1081^{\text {st }}-1082^{\text {nd }}$ have changed. $\mathrm{Y} 1301$ had base deletions at 915 and 976 , and $\mathrm{Y} 1302$ had base deletions at 816 and 867, respectively(Fig.4, Fig.5).

\section{Conclusion}

In this test, 5 isolated strains of Yersinia enterocolitica were identified via traditional biochemical, Pathogenicity identification and drug resistance testing. The result is that they were identified as Yersinia enterocolitica with severe drug resistance. At the same time, a phylogenetic tree was constructed based on the 16S rRNA gene of Yersinia enterocolitica, and the results showed that Yersinia enterocolitica isolated from Qinghai Lake naked carp located in the Qinghai-Tibet Plateau was an independently evolved cluster. Compared to other strains isolated from non-Tibet Plateau, they show clear regional differences. By routine identification and identification of Yersinia enterocolitica from naked carp of Qinghai Lake and detection of drug-susceptible flora, the interspecies distribution and drug distribution of Yersinia from naked carp of Qinghai Lake can be found out. Sensitive fauna lays a theoretical foundation for future research on key control points for preventing the disease. The theoretical and practical significance of protecting local special animal resources, exploring ways and capabilities to adapt to the environment, and laying a research foundation for comprehensively protecting the biodiversity of the Qinghai-Tibet Plateau. 


\section{Discussion}

The results of the drug susceptibility test showed that the resistance rate of five strains to 14 types of drug susceptibility tests exceeded $50.00 \%$. Y1301 is resistant to 9 drugs: $\mathrm{CH}, \mathrm{E}, \mathrm{CAZ}, \mathrm{K}, \mathrm{AMP}, \mathrm{PIP}, \mathrm{CMZ}, \mathrm{K}$, $P$, S300, SXT, and C. The drug resistance rate is $56.25 \%$ (9/16). No. 2 is resistant to 11 drugs: $A Z I, C H, E$, AN, CAI, AMP, CMZ, P, K, P, E, S300, and SXT, with a drug resistance rate of $68.75 \%$ (11/16). No. 3 has resistance to 10 drugs, AZI, CH, PIP, AMP, K, P, S300, SXT, and C, with a drug resistance rate of $62.50 \%$ (10/16). No. 4 has resistance to 9 drugs: CH, AN, CAZ, TE, TM, CMZ, P, SXT, and C. The drug resistance rate is $56.25 \%(9 / 16)$. No. 5 is resistant to five drugs, AZI, CH, E, AMP, P, and S300, with a resistance rate of $31.25 \%(5 / 16)$. The results of the drug sensitivity test showed that the isolate was highly sensitive to two drugs, gentamicin and tobramycin, but resistant to penicillin. Therefore, these high-sensitivity drugs can be selected for prevention and control in production. This result is different from the drug sensitivity characteristics of Yersinia isolated from spot fork tails infected by Y.e. The possible reason for the difference in drug sensitivity characteristics is that the strains in different regions and different water environments are exposed to the effects of different drug environmental effects, resulting in differences in drug resistance variations.

Because biochemical characteristics of Y.e are more complex, accurate biochemical test results are essential to identify Y.e. The isolates tested in this test were sucrose-positive, raffinose-negative, VP (26 $\left.{ }^{\circ} \mathrm{C}\right)$ positive, and VP $\left(37^{\circ} \mathrm{C}\right)$ negative, all of which were in line with typical Ye characteristics. In addition, the biochemical characteristics of other bacteria belonging to the genus Enterobacteriaceae were used. The biochemical characteristics of indole-positive and fermented sucrose can be distinguished from Yersinia pseudotuberculosis. At the same time, according to the biochemical characteristics of the isolates and the typical culture characteristics on $\mathrm{CIN}-1$ and modified $\mathrm{Y}$ medium, it can be clearly distinguished from the genera Proteus, Salmonella and Shigella. Finally, according to the Berger's Bacteria Identification Manual and Cai Miaoying's "Enterobacteriaceae Retrieval Line", the isolate was determined to be Y.E. Because this bacteria is a psychrophilic pathogen, it brings great difficulty to the isolation and identification. According to the National Standard for "Yersinia enterocolitica Test" (GB4789.8-2008) issued by the Ministry of Health of the People's Republic of China, by using the alkali treatment method in combination with $\mathrm{CIN}-1$ to select media and improve $\mathrm{Y}$, a better Separate selection effects was succeed. The detection medium for naked carp's solid organ Y.e shortened the inspection time by $3 d$, saved about $40 \%$ of raw materials, and improved the detection rate. On the one hand, it demonstrates the superiority of this method, and on the other hand, it also suggests the carrier rate in local naked carps. Five Y.e were isolated from the organs and gills of 75 naked carps collected, and the positive rate was $6.67 \%(5 / 75)$. According to the mouse pathogenicity test, it was found that one isolate had a lethal effect on mice. Retaining the naked carp carrying the pathogen is bound to cause hidden dangers to public health and safety.

\section{Declarations}

\section{Acknowledgments}


The authors would like to express their deep appreciation for the National Natural Science Foundation of China, which provided the funding for this research. We also thank all of the people who supported us in the field and the lab during this research.

\section{Funding}

Our research was supported by the "the National Natural Science Foundation of China" (Grant No.31560695) .

\section{Availability of data and materials}

All data generated or analyzed during this study and supporting the conclusions of this article are included within the article.

\section{Authors' contributions}

$\mathrm{ZH}, \mathrm{CQ}$ and ZJ conceived and designed the experimental concept. FY and KF collected the samples and extracted the DNA. TL and GX conducted the lab experiments. ZH and CQ wrote the paper. All authors reviewed the manuscript approved the final manuscript.

\section{Ethics approval and consent to participate}

No specific permits were required for this study.

\section{Consent for publication}

Not applicable.

\section{Competing interests}

The authors declare that they have no competing interests.

\section{Author details}

1. College of Agriculture and Husbandry, Qinghai university, Xining, China, 810016;2. Qinghai Academy of Animal Sciences and Veterinary Medicine, Qinghai University, Xining, China ,810016

\section{Highlights}

Our research firstly and fully isolated, identified and analyzed 16S rRNA gene of Yersinia enterocolitica strains from the Gymnocypris przewalskii in Qinghai Lake. Yersinia enterocolitica is an important pathogen of food which affected our food safety. Gymnocypris przewalskii is an very important wild fish lived only in Qinghai lake. It is a protection animals at the national level. It is critical for protection them on the view of disease investments. Our research supported this. 


\section{References}

1. Arguthority, E.F.S., The European Union summary report on trends and resources of zoonoses, zoonotic agents and food-brone outbreaks in 2010. EFSA Journal, 2012. 10(3): p. 2597.

2. M, M., K. G, and O. T, Liver abscess due to Yersinia bacteremia in a well-controlled type I diabetic patient. Endokrynol Pol, 2011. 62(4): p. 357-360.

3. Lupi, A., et al., Subacute endocarditis caused by Yersinia enterocolitica: a case report. Scand J Infect Dis, 2013. 45(4): p. 329-33.

4. Guinet, F., E. Carniel, and A. Leclercq, Transfusion-transmitted Yersinia enterocolitica sepsis. Clin Infect Dis, 2011. 53(6): p. 583-91.

5. Ong, K.L., et al., Changing epidemiology of Yersinia enterocolitica infections: markedly decreased rates in young black children, Foodborne Diseases Active Surveillance Network (FoodNet), 19962009. Clin Infect Dis, 2012. 54 Suppl 5: p. S385-90.

6. Kiskova, J., et al., Yersinia species in the dunnock (Prunella modularis) in sub-alpine habitats of the Western Carpathians. Pol J Microbiol, 2011. 60(1): p. 79-83.

7. Foti, M., et al., Pathogenic microorganisms carried by migratory birds passing through the territory of the island of Ustica, Sicily (Italy). Avian Pathol, 2011. 40(4): p. 405-9.

8. Fuchs, T.M., et al., Shotgun sequencing of Yersinia enterocolitica strain W22703 (biotype 2, serotype 0:9): genomic evidence for oscillation between invertebrates and mammals. BMC Genomics, 2011. 12: p. 168.

9. Xiao, Y., J. Liang, and W. Gu, Isolation and result analysis of yersinia enterocolitis in different animal hosts. Chinese Journal of Zoonoses, 2012. 28(5): p. 418-420.

10. Zhao, J., et al., The main biological characteristics of yersinia enterocolitis in pelagoba tepeloco. Journal of southwest Minzu university (natural science edition), 2013. 39(1): p. 12-16.

\section{Figures}

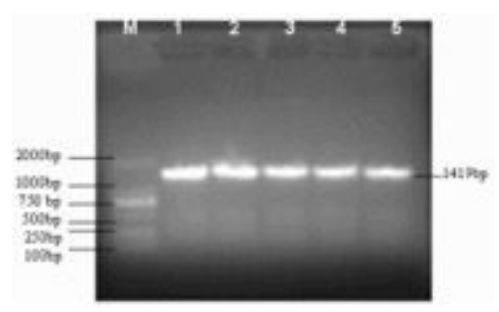

Figure 1

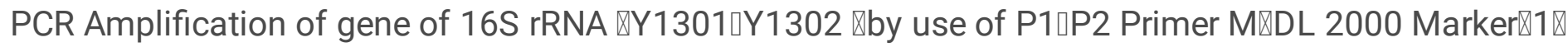

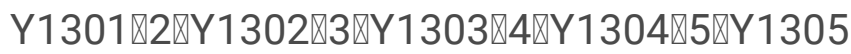




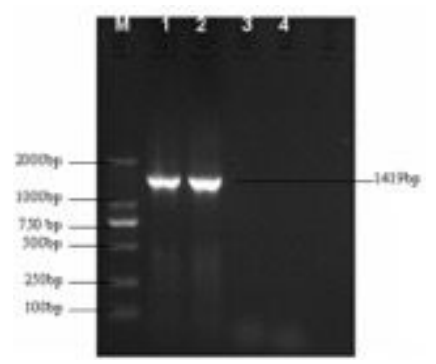

Figure 2

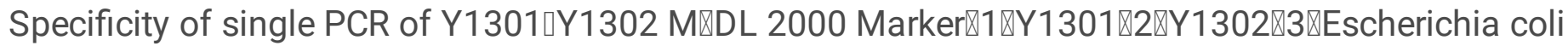

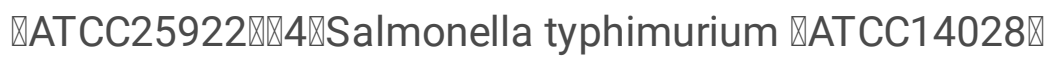

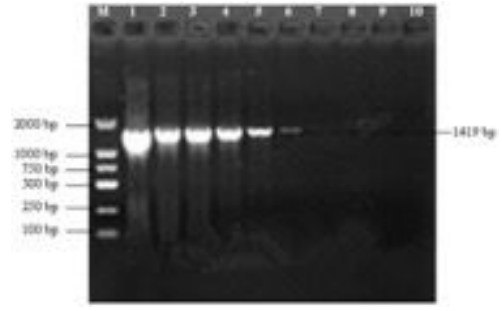

\section{Figure 3}

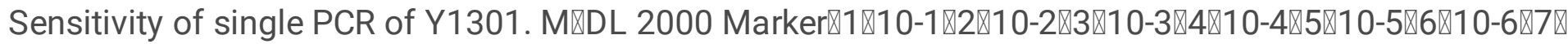
$10-7 \rrbracket 8 \otimes 10-8 \otimes 9 \otimes 10-9 \rrbracket 10 \otimes 10-10$
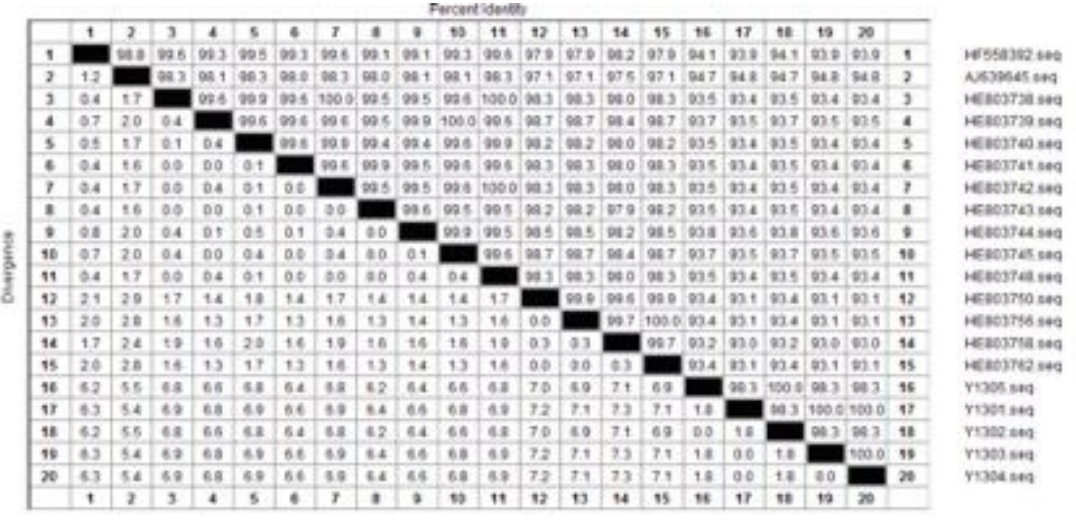

Figure 4

Analysis of genetic evolution of Y.e 16S rRNA gene from naked carp in Qinghai Lake 


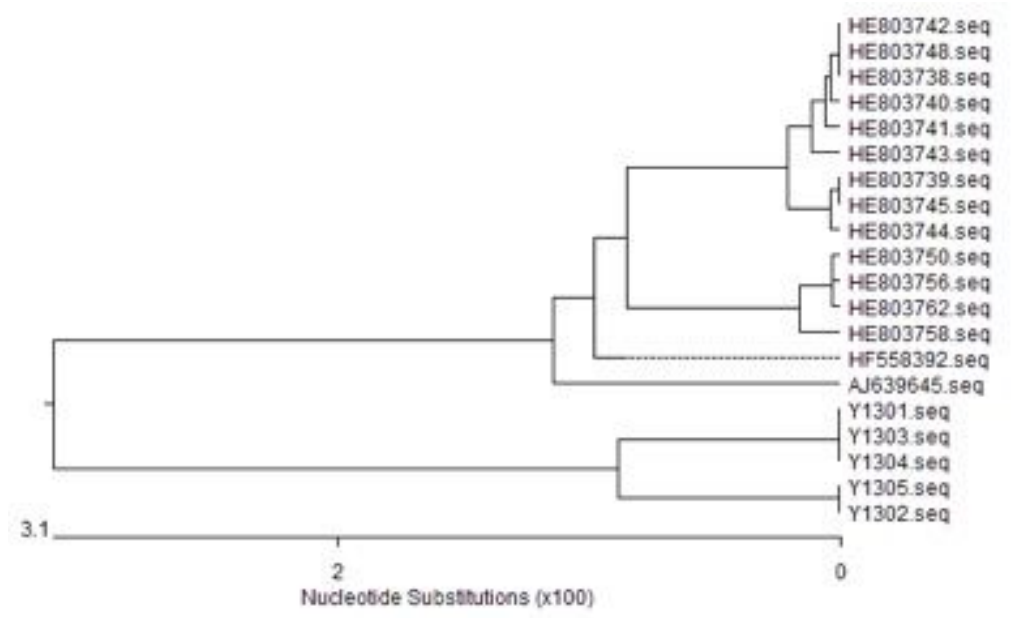

Figure 5

Phylogenetic Tree based on nucleotide sequence of 16S rRNA gene 